\title{
Natalia KLEJDYSZ
}

Uniwersytet im. Adama Mickiewicza, Poznań

\section{Widmo liberalizmu}

Widmo krąży po Europie, widmo komunizmu" - w ten sposób Karol "W Marks i Fryderyk Engels ponad sześćdziesiąt lat temu rozpoczęli „biblię” komunizmu naukowego, Manifest Komunistyczny. Współcześnie jednak trawestacja tych słów stała się hasłem krytyków liberalizmu. Liberalizm, odmieniany przez wszystkie przypadki, jest traktowany jako uprzedmiotowienie manichejskiego zła, a określenie „liberał” - stało się inwektywą. Pojawia się swoiste antynomie: dobro-liberalizm, człowiek cnotliwy-liberał. Przyglądając się kontekstowi tych wypowiedzi, nie sposób oprzeć się wrażeniu, że ich autorzy albo nie rozumieją czym jest liberalizm, albo też dokonują świadomego przekłamania.

Aby przybliżyć się do odpowiedzi na pytanie, czym jest antyliberalizm na polskiej scenie politycznej, musimy najpierw zdefiniować punkt odniesienia - a zatem... liberalizm. Nie sposób zliczyć publikacji poświęconych temu zagadnieniu. Tym jednak, co je łączy to obawa przed niejednoznacznością tego terminu. Friedrich August von Hayek w swej słynnej pracy Konstytucja wolności stwierdza: „Coraz bardziej zdaję sobie sprawę, że używanie tego słowa bez długich wyjaśnień wywołuje zbyt wiele nieporozumień i że jako hasło staje się ono bardziej balastem niż źródłem siły". Czy jednak kolejna definicja liberalizmu jest w stanie położyć kres mniej lub bardziej świadomemu zakłamywaniu faktów, które ma miejsce na polskiej scenie politycznej? Czy kolejna praca poświęcona liberalnym wartościom może zakończyć niebezpieczną zabawę w „liberalnego czarnego luda"?

Dlatego też spróbujmy problem przedstawić inaczej. Zastanówmy się nad tym, czym liberalizm nie jest. Nauczyciel F. A. von Hayeka, Ludwig von Mises, twierdził, że „Liberalizm nie jest religią ani żadnym światopoglądem, żadną partią specjalnych interesów. Nie jest religia, ponieważ nie wymaga ani wiary, ani poświęcenia; ponieważ nie ma nic mistycznego w liberalizmie [...]. Nie jest poglądem na świat, ponieważ nie próbuje

${ }^{1}$ F. A. von Hayek, The Constitution of Liberty, Chicago 1960, s. 408. 
wytłumaczyć wszechświata i ponieważ nie mówi nic i nie pragnie powiedzieć czegokolwiek o znaczeniu i celu ludzkiej egzystencji. Nie jest partią specjalnych interesów, ponieważ nie zaopatruje i nie pragnie zaopatrywać w jakiekolwiek specjalne korzyści żadnego indywidualnego człowieka czy żadnej grupy"2. Stanowisko to jednak nie jest powszechne zarówno wśród liberałów, jak i tych, którzy podjęli wyzwanie w postaci próby zdefiniowania liberalizmu ${ }^{3}$. A przede wszystkim od zgody na tego typu negatywną definicję dalecy są krytycy liberalizmu na polskiej scenie politycznej. Ich stanowisko wykazuje wiele podobieństw do tego, które obowiązywało w polskiej literaturze socjalistycznej. Ta jednostronna krytyka była jednak o tyle zrozumiała, że wynikała z antynomii myśli liberalnej i socjalistycznej. Jaka antynomia jednak przyświeca ortodoksyjnym krytykom liberalizmu współcześnie w Polsce? Przeciwko czemu protestują i na ile ten protest jest logicznym kontinuum preferowanego systemu wartości?

Odpowiedzi na te pytania należy szukać w wypowiedziach polskich polityków, a z drugiej strony - w wartościach stanowiących fundament liberalizmu. Jako pierwsze źródło przyjęto poniżej stanowisko partii najbardziej chyba antyliberalnej w Polsce (przynajmniej deklaratoryjnie) - Prawa i Sprawiedliwości. Drugie źródło natomiast jest o wiele bardziej złożone i, jeśli można tak stwierdzić, znacznie bardziej rozgałęzione. Historia liberalizmu sięga wprawdzie tylko (aż?) XVII wieku, jednak jego korzenie tkwią już w myśli starożytnej, a przede wszystkim wśród przedstawicieli, jak to określa Karl R. Popper, Wielkiej Generacji ${ }^{4}$. Wśród nich znaleźli się sceptyczni sofiści, a zwłaszcza Protagoras z Abdery, autor słów: „Miarą wszystkich rzeczy jest człowiek, istniejących, że istnieją, nieistniejących, że nie istnieją", uznawany dziś za twórcę koncepcji umowy społecznej, równości politycznej i demokracji uczestniczącej ${ }^{6}$, wybitny mówca i nauczyciel retoryki - Alkidamas, który, według Arystotelesa,

2 L. von Mises, Liberalizm w klasycznej tradycji. System społeczno-ekonomiczny, Nowy Jork 1989, s. III.

${ }^{3} \mathrm{~Np}$. M. Zmierczak twierdzi, że ,liberalizm jest pewną filozofią, światopoglądem, z którego wyciagnięto określone wnioski dotyczące także państwa i prawa”. M. Zmierczak, Ideologia liberalna w II Cesarstwie Francuskim, Poznań 1978, s. 7.

4 Chodzi o filozofów greckich, których aktywność przypada na czasy wojny peloponeskiej oraz okres ją bezpośrednio poprzedzający.

5 Protagoras, Prawda albo mowy obalajace, w: Historia idei politycznych. Wybór tekstów, t. I, opr. S. Filipowicz, A. Mielczarek, K. Pieliński, M. Tański, Warszawa 1998, s. 23.

${ }^{6}$ G. B. Kerferd, The Sophistic Movement, Cambridge 1981, s. 144. 
miał powiedzieć: „Bóg stworzył wszystkich wolnymi; natura nie uczyniła nikogo niewolnikiem"’ . Do tej samej generacji należał również Perykles. To przecież jego słynna Mowa pogrzebowa zawiera niewątpliwie najpełniejszą i najdojrzalszą w świecie starożytnym definicję fundamentalnych dla liberalizmu wartości: równości politycznej, indywidualizmu czy tolerancji: ,[...] każdy obywatel jest równy w obliczu prawa, jeśli zaś chodzi o znaczenie, to jednostkę ceni się nie ze względu na jej przynależność do pewnej grupy, lecz ze względu na talent osobisty, jakim się wyróżnia" ".

Z liberalnym dorobkiem Wielkiej Generacji zrywa Platon, a i Arystoteles, choć mniej jednoznacznie i łagodniej odrzuca wolność indywidualną i równość wobec prawa. Jak to określił John Gray, obaj - Platon i Arystoteles - dokonali kastracji greckiego liberalizmu'. Choć, jak twierdzi, etyka Arystotelesowska zawiera w sobie elementy późniejszej koncepcji przypisanych każdemu człowiekowi praw naturalnych.

Jednak to Marka Tuliusz Cycerona F. A. von Hayek uważa za najważniejszego liberała w świecie starożytnym ${ }^{10}$. „Cyceron, któremu zawdzięczamy wiele z najbardziej przekonujących opisów wolności w warunkach prawa, stał się w istocie czołowym autorytetem współczesnego liberalizmu"11. A zatem dzisiejsze definiowanie wolności w granicach prawa i skorelowanie jej z rządami prawa ma swoje źródło w starożytnym Rzymie.

Narodziny chrześcijaństwa zahamowały, choć nie wygasiły ognisk rozwoju pierwotnych idei liberalnych. Nabrały one jednak nowego znaczenia w odmiennym otoczeniu, a ich wymiar stał się apolityczny. Widać to szczególnie w odniesieniu do indywidualizmu wczesnochrześcijańskiego, który ujawnił się pod postacią koncepcji nieśmiertelności duszy. Był to niewątpliwie dorobek chrześcijaństwa ${ }^{12}$ - indywidualna zapłata za

7 Arystoteles, Rethorica I, XIII, $1373 \mathrm{~b} 18$.

8 Tukidydes, Wojna peloponeska, w: Historia idei, op. cit., s. 12.

9 Gray odwołuje się tutaj do E. A. Hovelocka. Patrz: J. Gray, Liberalizm, Kraków 1994, s. 15.

${ }^{10} \mathrm{Wg}$ Hayeka pierwotnie fundamentalne znaczenie dla pojmowania wolności w republice rzymskiej miało Prawo Dwunastu Tablic. F. A. von Hayek, Konstytucja wolności, Warszawa 2007, s. 171.

${ }^{11}$ Ibidem, s. 172.

12 Judaizm traktował nieśmiertelność duszy w sposób niezwykle zróżnicowany: tylko faryzeusze wierzyli w zmartwychwstanie sprawiedliwych i ukaranie bezbożnych, saduceusze odrzucali zmartwychwstanie, a esseńczycy wierzyli jedynie w przetrwanie dusz. 
uczynki życia doczesnego dla każdego człowieka ${ }^{13}$. Jednak pogląd ten mógł znaleźć dla siebie miejsce w każdej rzeczywistości politycznej i w każdym społecznym porządku.

Chrześcijaństwo pierwszych wieków położyło kres pojmowaniu tolerancji w paradygmacie starożytności, zainicjowało odmienne spojrzenie na wolność i indywidualność. Edykty cesarskie z 380 i 435 roku wykreowały nową rzeczywistość, w której nie było już miejsca na odmienność i wolnomyślicielstwo ${ }^{14}$. Mimo to, pewne idee protoliberalne rozwijają się w okresie średniowiecza niejako „podskórnie”. Św. Tomasz z Akwinu w Summie teologicznej wypowiada się na temat wolności umów i han$\mathrm{dlu}^{15}$. A jego kontynuator, franciszkanin, Ryszard z Middleton opisał dwie determinanty wartości dobra gospodarczego: potrzebę i użyteczność. Natomiast Pierre de Jean Olivi, również członek zgromadzenia franciszkańskiego, uznał, że „wartość ekonomiczna określana jest przez trzy czynniki: rzadkość (łac. raritas), użyteczność (łac. virtuositas) i chęć posiadania, pragnienie (łac. complacibilitas)"16. Wątek ten będzie rozwijał nieco później francuski filozof, Jean Burdian de Bethune, uczeń Williama Occama. Namiastka myśli liberalnej pojawia się zatem w drugiej połowie wieków średnich w odniesieniu do relacji popytu i podaży, a więc ogranicza się do płaszczyzny ekonomicznej. Na próżno szukać w wypowiedziach mediewalnych myślicieli rozważań na temat wolności czy indywidualności człowieka, bezowocne będą również próby odnalezienia w ich dziełach koncepcji równości wobec prawa czy postulatów tolerancji religijnej. Można stwierdzić, że wartości te odeszły wraz ze światem starożytnym. W myśli średniowiecznej zyskały kontekst eschatologiczny, nie pozwa-

13 Nowy Testament, Ewangelia wg Mateusza, 22, 23-33.

14 Edykt z 380 roku nakazywał utrzymywanie w hańbie heretyków, a ponadto „czeka ich kara boża a potem także zrodzona z naszego gniewu, którą im zgodnie z wolą bożą okażemy”, a w dokumencie z 435 roku stwierdzano wprost: „Wszystkim osobom występnego wyznania pogańskiego zakazujemy składania obrzydłych ofiar, [...]. Nakazujemy wszystkie ich święte miejsca zniszczyć [...]. Wszystkim niech będzie wiadomo, że jeśli ktoś drwi z niniejszego rozporządzenia, a zostanie to w wystarczający sposób udowodnione przed odpowiednim sędzią - ma być ukarany śmiercią". Historia państwa i prawa. Wybór tekstów źródłowych, red. B. Lesiński, Poznań 1995, s. 27 i 29.

15, ,...] kupowanie i sprzedawanie wydaje się być zinstytucjonalizowane dla wzajemnej korzyści obu stron, ponieważ jedna ze stron potrzebuje czegoś, co należy do kogoś innego, i odwrotnie, ktoś inny posiada coś, czego pragnie druga strona" - cyt. za: W. Kwaśnicki, Historia myśli liberalnej, Warszawa 2000, s. 30.

16 Ibidem. 
lając na jakiekolwiek spekulacje poza tę sferę wykraczające. Niewątpliwie, wyłomem jak i przełomem był tak zwany prerenesans. Myśliciele tej epoki wprowadzają dysonans do tradycyjnego pojmowania średniowiecza. Bo przecież indywidualizm i rozważania na temat wolności filozoficznej i politycznej to determinanty doktryny, wspomnianego już wcześniej, Williama Occama. To jemu przecież zawdzięczamy nowożytną, liberalną koncepcję praw i uprawnień jednostki. „Wraz z prezentacją nowego ujęcia wolności pojawiła się u Ockhama propozycja istotna dla dalszych dziejów myśli prawnej: separacji wolności oraz natury i [prawa - N.K.] rozumu towarzyszyło przeciwstawienie jednostki społeczeństwu, a jej indywidualnych uprawnień normom wspólnotowym" ${ }^{17}$. Marsyliuszowska koncepcja prawa i sprawiedliwości formalnoprawnej oraz wizja relacji państwo-Kościół, oparta na zgoła nowych przesłankach i do nowatorskich wniosków wiodąca, wprawdzie antyindywidualistyczna, ale stanowi dowód na „otwieranie się” odważnych pisarzy średniowiecza na tradycje starożytne, zwłaszcza rzymskie, w pojmowaniu tolerancji religijnej. Trudno dziś sobie wyobrazić jak wielką odwagą i otwartością umysłów musieli wykazać się myśliciele prerenesansowi, by, niejako „w poprzek” obowiązującym od wieków zasadom, wystąpić otwarcie przeciwko Kościołowi, jego doktrynie i potędze.

W wieku XVI jednak, również pośród funkcjonariuszy Kościoła, utrzymało się liberalne podejście do zagadnień ekonomicznych. Częściowo było ono wymuszoną reakcją na bunt reformatorów, ale w pewnej części stanowiło kontynuację ujęcia tomistycznego w tym zakresie. Dlatego też nie sposób pominać wkładu w rozwój myśli liberalnej jezuitów i dominikanów związanych ze szkołą w Salamance. Interesujące nas rozważania przedstawicieli tej szkoły ogniskowały się na zagadnieniu wolnego ryku (!). ,Scholastycy ci twierdzili, że z praktycznego i moralnego punktu widzenia wolny rynek był zawsze lepszy od etatyzmu. Zajmowali się takimi problemami gospodarczymi jak kształtowanie się cen, ilość pieniądza na rynku, rachunek ekonomiczny, stosunek do własności kolektywnej itp."18 Problematyką tą zajmował się na już na początku XVI wieku Francisco de Vitoria czy, już w okresie poreformacyjnym, Diego de Covarrubias y Levia. W duchu nowożytnej argumentacji swoje poglądy na temat sprawiedliwej ceny sformułował przede wszystkim Luis de Molina:

17 B. Szlachta, Prawo, w: Słownik społeczny, Kraków 2004, s. 991.

18 W. Kwaśnicki, op. cit., s. 32. 
„[...] sprawiedliwa cena dowolnego towaru zależy zasadniczo od powszechnej oceny jego wartości przez ludzi mieszkających na danym terytorium"19. Natomiast zagorzałym obrońcą własności był inny jezuita, Juan de Mariana, twierdząc, że król „nie ma praw do dóbr ludzkich i nie może zabierać ich własności w całości lub w części" ${ }^{20}$, a Domingo de Soto kilka lat później podkreślał: „Dlatego dobra w rękach prywatnych będa pomnażane. Kiedy natomiast byłyby w powszechnym władaniu, całkiem coś przeciwnego byłoby prawdą"21.

Za symboliczny moment narodzin liberalizmu nowożytnego uznaje się często rok 1688 - „chwalebną rewolucję” w Anglii. Natomiast personalnie z jego początkami utożsamiany jest John Locke. Odkładając na chwilę ten bezdyskusyjny fakt, lecz pozostając w siedemnastym stuleciu, należy jednak w pierwszej kolejności przywołać postać Hugo Grocjusza ze względu na jego zlaicyzowaną i zracjonalizowaną koncepcję prawa natury, a także nowoczesną koncepcję praw podmiotowych. Dzięki tym dwóm konstrukcjom holenderski pisarz stworzył podstawy klasycznie rozumianego państwa liberalnego. Nie sposób pominąć również autora słynnego Lewiatana, Thomasa Hobbesa, który dał nam ,pierwszy systematyczny wykład współczesnej myśli indywidualistycznej”22, a także opracował koncepcję wolności negatywnej. Mimo niewątpliwych zasług Hobbesa w tym zakresie, Benedykt Spinoza przedstawił problem wolności w sposób znacznie dojrzalszy, łącząc go z osiąganiem celu przez każdą jednostkę. Co ciekawe, mimo zbliżonego sposobu myślenia, obaj, Hobbes i Spinoza, doszli do diametralnie różnych wniosków. Według autora O prawie wojny $i$ pokoju najskuteczniejszym gwarantem wolności jest ustrój demokratyczny, dla Hobbesa natomiast - władza absolutna, choć twórca Lewiatana dodaje: „Chciałem, iżby się nie wydawało, że ja uważam, iż państwu arystokratycznemu czy demokratycznemu należy się mniejsze posłuszeństwo ze strony poddanych niż państwu monarchistycznemu. [...] wyraźnie mówię, że każdemu państwu należy dawać władzę najwyższą i jednakową"23. Czy możemy zatem, na tej podstawie stwierdzić, że dla Hobbesa nieistotny jest ustrój? Czym byłaby władza absolutna

19 Cyt. za: ibidem, s. 33.

20 Cyt. za: ibidem.

21 Cyt. za: ibidem, s. 35.

22 J. Gray, op. cit., s. 20. Tę opinię Gray podziela z Leo Straussem czy Michaelem Oakeshottem.

23 T. Hobbes, Elementy filozofii, t. II, Warszawa 1956, s. 196. 
w warunkach demokratycznych? Czy w związku z tym możemy Hobbesowską koncepcję państwa - ustroju sprowadzić do jego wydolności i autorytetu? A co w takiej sytuacji zrobić z jego wyraźnym przywiązaniem do monarchii? Odpowiedzi na te pytania wymagają obszerniejszego wywodu, jednak można pokusić się o przywołanie samej konkluzji. Hobbes nie był liberałem, tak samo jak nie był nim Spinoza czy Tomasz z Akwinu, lecz, tak jak i oni, zasługuje on na miano prekursora myśli liberalnej.

Mianem twórcy spójnej tradycji intelektualnej liberalizmu możemy określić dopiero Johna Locke'a. „U Locke'a znajdujemy to, czego brakowało u wcześniejszych pisarzy indywidualistycznych: wyraźne wskazanie, że wolność osobista implikuje prywatną własność silnie chronioną przepisami prawa" ${ }^{24}$. Zdefiniowanie stanu natury, stanu przedpaństwowego, w oparciu o kategorię praw naturalnych, pozwoliło Locke'owi skonstruować w pełni liberalną koncepcję państwa, które zostaje powołane tylko po to, aby rzeczone prawa naturalne: do życia, do wolności i do własności, były pełniej gwarantowane i aby to państwo właśnie zdjęło z ludzi brzemię i niewygodę rozsądzania spraw w stanie natury. Pojawia się więc w pełni dopracowana koncepcja państwa „małego”, o kompetencjach ograniczających się jedynie do zadań wypływających z przesłanek zawarcia umowy społecznej. U Locke'a podstawą państwa liberalnego jest społeczeństwo obywatelskie rozumiane jako „ci, którzy są zjednoczeni w jednej społeczności, podlegają wspólnie ustanowionemu prawu, posiadają trybunał, do którego mogą się odwołać, a który dysponuje autorytetem władnym rozstrzygać spory między nimi i karać przestępców [...]"25. W przeciwieństwie do Hobbesa Locke wyraźnie odrzuca pożytek płynący z władzy absolutnej. To zrozumiałe, jeśli jako fundament przyjmiemy społeczeństwo obywatelskie. Thomas Hobbes nie posługuje się tą kategorią, a ponadto pisze on wyraźnie o konieczności istnienia władzy absolutnej, a nie monarchii absolutnej. Według Locke’a „Władza publiczna całego społeczeństwa rozciagga się na każdą jednostkę należącą do tego społeczeństwa. Najważniejszą korzyścią pochodzącą od tej władzy, a dotyczącą wszystkich, którzy jej podlegają, jest stanowienie praw"26. Służyć ma temu autorska koncepcja podziału władzy ${ }^{27}$. Wypływa więc z Locke’ow-

24 J. Gray, op. cit., s. 26.

25 J. Locke, Dwa traktaty o rzqdzie, Traktat drugi, Warszawa 1992, s. 223.

26 Ibidem, s. $225 \mathrm{w}$ przypisie.

27 Locke wyodrębnia legislatywę, egzekutywę i władzę federacyjną (polityka zagraniczna), jednak to tylko dwóch pierwszych władz dotyczy zasada rozdzielności. 
skiego projektu liberalna koncepcja rządów prawa rozumiana jako „wolność ludzi pod władzą rządu”, a to oznacza ,[...] życie pod rządami stałych praw, powszechnych w tym społeczeństwie i uchwalanych przez powołaną w nim władzę ustawodawczą"28.

W tym momencie na chwilę porzucimy tropienie śladów liberalizmu w przeszłości. Ale cóż wynika z dotychczasowych ustaleń w tej kwestii? Otóż pierwotna formuła liberalnej wolności i indywidualizmu - dwóch fundamentalnych dla tego nurtu wartości - narodziła się już w starożytności. To Grecy - Ateńczycy ${ }^{29}$ wolności w sensie fizycznym nadali wymiar polityczny. To oni również zaczęli postrzegać człowieka jako odrębną wartość, jako jednostkę, która sama jest w stanie ocenić, co dla niej istnieje, a czego nie ma. To średniowiecznym filozofom i teologom (!) zawdzięczamy priorytet własności i nadanie mechanizmom wolnego rynku należytej rangi. To w końcu w XVII wieku wartości te zespolono z instytucjami politycznymi i stworzono koncepcję państwa minimalnego - liberalnego właśnie.

Osiemnastowieczny ferment intelektualny, zwany Oświeceniem, przyniósł liberalizmowi dynamiczny i wielokierunkowy rozwój. To właśnie za sprawą wielkiej wiary w człowieka, w samego siebie, zgodnej z hasłem epoki, Sapere aude!, myśl liberalna rozpadła się na kilka nurtów. Jednak proces ten nie osłabił liberalizmu, a wręcz przeciwnie - spowodował, że stał się on ofertą intelektualną znacznie ciekawszą, elastyczniejszą i dynamiczną. Monteskiusz, bazując na relatywizmie Arystotelesowskim, stworzył koncepcję ducha praw. Jeśli przeniesiemy jej zasady na grunt myśli liberalnej, będziemy mogli mówić o duchu liberalizmu. Rozwijając się relatywnie względem odmiennych warunków geograficznych, społeczno-politycznych, ekonomicznych i kulturowych, liberalizm przestał być jednym liberalizmem. Zaczyna się epoka liberalizmów.

W pierwszej kolejności duch liberalizmu uzewnętrznił się poprzez zróżnicowanie między liberalizmem angielskim a liberalizmem kontynentalnym (zwłaszcza francuskim). Wprawdzie Anglia jest kolebką liberalizmu, to jednak nie może oznaczać uniwersalizacji angielskiej myśli liberalnej. Gdy w XVII wieku w Anglii rozwija się parlamentaryzm, we Francji nadal królował absolutyzm, mimo wysiłków Stuartów, Karola II, a zwłaszcza Jakuba II, by przy pomocy i na wzór ustroju francuskiego, częściowo bazując na modelu brytyjskim sprzed rewolucji purytańskiej,

28 J. Locke, op. cit., s. 178-179.

29 Choć wielu spośród nich przybyło do Aten z innych polis. 
stworzyć angielską odmianę francuskiego absolutyzmu. Nie powiodło się to, zarówno na skutek odmiennych tradycji instytucji politycznych, a także nieudolności Jakuba II. Brak tradycji parlamentarnych oraz słabo w tym czasie rozwinięta idea indywidualistyczna stanowiły o różnych drogach rozwoju obu liberalizmów.

Tym, co zdecydowało o odmienności liberalizmu francuskiego i angielskiego była również religia. Na tej płaszczyźnie drogi protestanckiej Anglii i wybitnie katolickiej Francji zdecydowanie się rozeszły w wieku XVI. W efekcie liberalizm francuski zyskał bardzo silne zabarwienie antyklerykalne, inaczej niż nonkonformizm angielski.

Mimo to liberalizm francuski bardzo chętnie, w początkowej fazie swego rozwoju sięgał do wzorców angielskich. Wyraźnie widać to u Monteskiusza, którego dzieło $O$ duchu praw powstało pod wpływem podróży i z inspiracji angielskim modelem.

Wspólnym dla Francji i Anglii przełomem, choć o odmiennych skutkach, stała się Rewolucja Francuska. Dla Anglików była ona katalizatorem konserwatyzmu o liberalnym zabarwieniu, dla Francuzów - ,gwarantyzmu", który w pierwszej połowie następnego wieku będzie rozwijany przez tzw. „doktrynerów”, Benjamina Constanta czy F. P. G. Guizota, pozostających pod znacznym wpływem tradycji i praktyki angielskiego konstytucjonalizmu.

B. Constant, którego śmiało możemy nazwać anglofilem, stał się, najbardziej zagorzałym krytykiem koncepcji demokracji Jana Jakuba Rousseau, co niewątpliwie zostało sprowokowane nie tyle poglądami autora O umowie społecznej, ile przebiegiem samej rewolucji. Skonstruowana przezeń dychotomiczna koncepcja wolności ${ }^{30}$ pozwoliła mu i późniejszym

30 „Wolność jest prawem każdego człowieka do podlegania przepisom prawa, prawem do tego, aby nie być aresztowanym, sądzonym i uśmierconym czy też w żaden inny sposób prześladowanym z powodu kaprysu jednej lub wielu jednostek. Jest to prawo każdego do wyrażania swoich opinii, [...] prawo każdego do wpływu na zarządzanie państwem [...]. Porównajmy tę wolność z wolnością starożytnych. Tamta polega na zbiorowym, ale bezpośrednim korzystaniu z wielu przywilejów władzy, radzeniu nad dobrem publicznym, nad wojną i pokojem, uchwalaniu praw, wydawaniu wyroków, badaniu wydatków itd.; uważając to za składniki wolności, starożytni utrzymywali jednak, że wszystko daje się pogodzić z podporządkowaniem jednostki władzy społecznej [...]. Starożytnych, jednostka suwerenna w sprawach publicznych, jest niewolnikiem we wszystkich relacjach prywatnych. Współcześnie jest przeciwnie, jednostka niezależna w życiu prywatnym, jest w nawet najbardziej wolnym państwie, suwerenna jedynie z pozoru" - B. Constant, Liberty Ancient and Modern, cyt. za: G. de Guggiero, The History of European Liberalism, Oxford 1927, s. 167-168. 
„gawrantystom” na uzasadnienie tezy, że wolność jednostki i demokracja nie są ze sobą nierozerwalnie związane i mogą istnieć bez siebie. Natomiast zagrożenia wypływające $\mathrm{z}$ demokracji dla indywidualizmu opisał Alexis de Tocqueville, choć jego ocena nie była tożsama $\mathrm{z}$ odrzuceniem demokracji w ogóle, lecz próbą rozwiązania konfliktu między dyktatem większości a wolą jednostki.

Własną drogą rozwijał się również liberalizm w Niemczech i we Włoszech. Rozbicie terytorialne i polityczne determinowało treść dyskursu intelektualnego nie tylko do momentu zjednoczenia, ale również później, w wieku XIX. Podobny problem dotyczy polskiej myśli liberalnej. Brak państwowości w ogóle uniemożliwił stworzenie własnego projektu liberalnego, a dążenia państwowotwórcze, później odbudowa instytucjonalna państwa, na trwałe zdominowały myśl polityczną do II wojny światowej.

W drugiej połowie XVIII wieku pojawia się kolejna „odnoga” liberalizmu europejskiego. Bo oto na arenę polityczną wstępują Stany Zjednoczone Ameryki Północnej - państwo, które na liberalizmie powstało. Jednak liberalizm amerykański również był od samego początku zróżnicowany, a składał się nań: „,radykalizm Jeffersona, umiarkowanie Madisona i amerykański toryzm Hamiltona"31.

Pierwszy wyraźny podział w liberalizmie europejskim nastapił w drugiej połowie XIX w. „Sprawcą” był utylitaryzm. Jego twórca, Jeremy Bentham $^{32}$, pozostając zdeklarowanym leseferystą i zagorzałym obrońcą indywidualnej wolności, za podstawowy czynnik moralno-twórczy uznał przyjemność, która stanowi podstawę „rachunku szczęścia”33. Stanowił on podstawę Benthamowskiego przekonania o możliwości racjonalnego udoskonalania instytucji społecznej. Paradoksalnie, to założenie w przyszłości będzie podstawą interwencjonizmu inżynierii społecznej.

Przełomem w dziewiętnastowiecznym liberalizmie, który był niewątpliwie kontynuacją procesu rozpoczętego przez Benthama i Jamesa Milla, stała się filozofia polityczna Johna Stuarta Milla. Doprowadził on bowiem do zerwania z klasycznym liberalizmem i narodzin nowego nurtu zwanego liberalizmem socjalnym. W związku z tym możemy uważać go za pisarza przełomu między starą a nową myślą liberalną. Nie oznacza to jednak, iż stary liberalizm odpłynął w niebyt. Jeszcze w XIX wieku pojawiali się

31 J. Gray, op. cit., s. 37.

32 Również jego uczeń James Mill, autor racjonalistycznej obrony demokracji.

33 Ks. Tadeusz Ślipko SJ, Etyka, w: Słownik społeczny, op. cit., s. 276. 
kontynuatorzy klasycznej linii leseferyzmu, jak choćby Herbert Spencer, lecz jego wpływ na angielską filozofię liberalną nie był znaczący.

Natomiast zainicjowany przez J. S. Milla rewizjonizm liberalny wkrótce znalazł znamienitych kontynuatorów, np. Thomasa H. Greena, który spopularyzował podział na wolność negatywną i pozytywną, sam stając się obrońcą koncepcji wolności jako możliwości ${ }^{34}$, a także Francisa Bradleya czy Bernarda Bosanqueta. Systematyczny wykład nowego liberalizmu pojawił się w 1911 roku w pracy Liberalism Leonarda Hobehouse'a. Odrzucając atomistyczną koncepcję społeczeństwa, Hobehouse jednocześnie skrytykował leseferyzm starego liberalizmu, jak i ideologie autorytarne. Bazując na pozytywnej koncepcji wolności uzasadniał interwencjonizm państwa $\mathrm{w}$ interesie słabszych i pokrzywdzonych.

Niewatpliwie na kształt i sam fakt zaistnienia liberalizmu rewizjonistycznego wpływ miał wzrost popularności myśli i ruchów socjalistycznych. To socjalizm właśnie, z jednej strony, stał się katalizatorem refleksji liberalnej, z drugiej - sprowokował, w odruchu swoistej samoobrony przed marginalizacją liberalizmu, wprowadzenie do kanonu wartości liberalnych nowych treści, a interpretacji - starych.

Upadek klasycznego liberalizmu przypieczętowała I wojna światowa, a jednocześnie wytworzyła klimat sprzyjający rozwojowi nurtów rewizjonistycznych liberalizmu. Kryzys gospodarczy przełomu lat 20. i 30 . utwierdził zwolenników interwencjonizmu państwowego w przekonaniu o konieczności zwiększenia zakresu kompetencji państwa nie jako rozwiązania doraźnego, lecz długofalowego, wpisującego się w projekt nowego państwa opartego na nowym liberalizmie. Stąd popularność teorii ekonomicznej (czy, jak twierdzą jego przeciwnicy - spekulacji) Johna Maynarda Keynes'a, którą wdrożono do programu naprawczego Nowego Ładu.

Mimo ciosu, jakim dla liberałów był wzrost popularności doktryn socjalistycznych oraz I wojna światowa, w latach 30 . XX wieku istniało kilka ośrodków myśli liberalnej ${ }^{35}$, choć ich charakter i znaczenie było czysto akademickie. Było to zapewne podyktowane rozproszeniem i hermetyczno-

34 Wolność jako możliwość związana jest z koncepcją wolności pozytywnej.

35 Były to: grupa londyńska (na czele - E. Cannan), grupa austriacka (L. von Mises), grupa amerykańska (F. H. Knit), grupa niemiecka (W. Eucken); istniały również ośrodki liberalizmu we Włoszech i we Francji. Patrz. W. Sadurski, Neoliberalny system wartości politycznych, Warszawa 1980, s. 67-69. 
ścią każdego z nich. Brakowało wspólnych inicjatyw, które zadziałałyby konsolidująco.

Zatem odpowiedzią na wzrost popularności liberalizmu socjalnego było zorganizowanie w przededniu II wojny światowej, w sierpniu 1938 roku, Kolokwium Lippmanna, czyli debaty nad teorią liberalną ${ }^{36}$. Efekty tegoż spotkania, mimo że brały w nim udział najwybitniejsze autorytety związane z myślą liberalną ${ }^{37}$, były raczej skromne. Dyskusja toczyła się wokół przyczyn kryzysu liberalizmu, a znaczną część czasu zabrał spór na temat nazwy, którą współczesny, prawdziwy liberalizm miałby być określany. Zaproponowany i zaakceptowany przez większość neoliberalizm doprowadził jednak do sporu nad przedrostkiem neo. Część uczestników uważała, że nowa nazwa jest myląca czy wręcz błędna, ponieważ sugeruje, że mamy do czynienia z czymś jakościowo nowym, a zamiarem Kolokwium była restauracja liberalizmu klasycznego i przystosowanie go do nowych czasów ${ }^{38}$.

Wybuch II wojny światowej uniemożliwił podjęcie inicjatywy zapoczątkowanej w 1938 roku. John Gray wręcz twierdzi, że „klasyczny liberalizm został poważnie zraniony przez katastrofę I wojny światowej, natomiast II wojna go zabiła" ${ }^{39}$. To dramatyczne stwierdzenie nie do końca jest jednak prawdziwe. Pozostając w tej stylistyce wypowiedzi, można stwierdzić, że swą reanimację liberalizm zawdzięcza konferencji w Mont-Pelerin. Oprócz większości uczestników Kolokwium Lippmanna, wzięli w niej udział, m.in. W. Eucken, M. Friedman, B. de Jouvenel, F. Machlup czy K. R. Popper ${ }^{40}$. Spotkanie, które odbyło się w kwietniu 1947 roku, ponownie połączyło liberałów różnych nurtów i środowisk. Jako efekt końcowy jednodniowych obrad powołano Towarzystwo Mont-Pelerin, a jego pierwszym przewodniczącym został F. A. von Hayek. Mimo że Towarzystwo to wciąż istnieje, starając się wypełniać swe statutowe cele, to neoliberalizm, mamy wrażenie, na stałe został zepchnięty przez rewizjonistyczne nurty socjalne.

36 Pretekstem do tego spotkania stało się wydanie i ukazanie się w tłumaczeniu francuskim książki The Goog Society Waltera Lippmanna. Książka ta była próbą pogodzenia liberalizmu klasycznego z wymogami i oczekiwaniami nowej epoki.

37 W spotkaniu wzięło udział 25 uczonych, m.in.: R. Aron, F. A. von Hayek, M. Polanyi, W. Röpke, L. Rougier (organizator spotkania), A. Rüstow, W. Lippmann.

38 W. Sadurski, Neoliberalny system wartości politycznych, Warszawa 1980, s. 69 i 74-75.

39 J. Gray, op. cit., s. 51.

40 W sumie 36 uczestników z 9 krajów. 
Byłoby jednak błędem przyjąć, że liberalna scena ma charakter dychotomiczny: z jednej strony socjoliberalizm, a z drugiej - neoliberalizm (liberalizm konserwatywny). Myśl liberalna XX i XXI wieku to zjawisko niezwykle dynamiczne. Wielość nurtów i ich zmienność fascynuje, ale również nastręcza liczne problemy definicyjne. Lata 70 . XX wieku przyniosły bowiem odrodzenie liberalizmu w filozofii politycznej pod postacią teorii sprawiedliwości społecznej Johna Rawlsa, który usiłował rozwiązać konflikt egalitaryzmu z wolnością, co zaowocowało powstaniem konstruktu sprawiedliwości jako bezstronności. Ale w tym samym czasie rodzi się (niejako w odpowiedzi na koncepcję Rawlsa) libertarianizm, który w swej skrajnej postaci nazywany bywa anarcholiberalizmem czy też anarchokapitalizmem. Jednak i sam libertarianizm ma zarówno postać radykalną (M. Rothbard), jak i umiarkowaną (R. Nozick). Swe miejsce pomiędzy dwoma biegunami, których wyznacznikami będą: wolność negatywna-wolność pozytywna, państwo minimalne-państwo opiekuńcze, sprawiedliwość formalnoprawna-sprawiedliwość społeczna, indywidualizm-koncepcja jednostki społecznej, otóż pomiędzy tymi wyznacznikami rozwinął się nurt zwany liberalizmem realnym, za którego twórcę uznajemy W. Lippmanna, a który próbował, rozczarowawszy się polityką Theodore'a Roosevelta, „uczłowieczyć” liberalizm klasyczny. Z kolei blisko socjalnego liberalizmu w latach 50 . XX wieku pojawił się kapitalizm ludowy Adolfa Berle, a już przed II wojną światową w środowisku liberałów niemieckich narodził się ordoliberalizm, który stanowi doskonały przykład współistnienia liberalizmu klasycznego, poddanego racjonalnej weryfikacji, i nauki społecznej Kościoła ${ }^{41}$. Nie sposób pominąć, sytuującej się blisko tradycji kontraktualistycznych, teorii racjonalnego wyboru, która rozwinęła się w pełni w latach 80 . XX wieku ${ }^{42}$. Za jej twórcę uznawany jest James Buchanan ${ }^{43}$, laureat nagrody Nobla w dziedzinie ekonomii ${ }^{44}$. Należy wspomnieć również o liberalizmie pluralistycznym, którego twórcą jest Isaiah Berlin, natomiast kontynuatorem Joseph Raz.

41 Jednym z teoretycznych fundamentów ordoliberalizmu jest doktryna społecznej gospodarki rynkowej, która stanowiła podstawę powojennych, zakończonych sukcesem reform w Niemczech.

42 Jej początki sięgają jednak lat 50. XX wieku.

$43 \mathrm{~W}$ gronie współtwórców tej teorii należy wymienić: G. Tullocka, A. Downa, M. Olsona, a także D Gautiera.

44 J. Buchanan otrzymał nagrodę Nobla w 1986 roku; interesujący jest fakt, że wśród obrońców liberalizmu znajdziemy jeszcze co najmniej dwóch noblistów - F. A. von Hayek (1972 r. - wraz z G. Myrdalem) oraz M. Friedman (1976 r.). 
Z nurtem tym jest przecież związany również, wspominany wielokrotnie, John Gray, choć on sam określa siebie mianem postliberała ${ }^{45}$.

Polimorfizm liberalizmu zdaje się uniemożliwiać stworzenie jednej wspólnej definicji. Jednak istnieje inna metoda definiowania liberalizmu, czy też liberalizmów. W pierwszej kolejności należy zwrócić uwagę na to, iż, mimo że poszczególne nurty liberalizmu znacznie się względem siebie różnią, a niekiedy nawet wydają się sprzeczne, to jednak wciąż mamy do czynienia z liberalizmem! Bez względu na to czy mówimy o Benthamie czy Faque'cie, Buchananie czy Popperze, Galbraicie czy Nozicku - mówimy o liberałach! Liberalizm przypomina bowiem wielki gmach, w którym zamiast jednego wspólnego pomieszczenia, mamy liczne różniące się kwatery. Jednak fundament, ściany i dach są wspólne.

Bez względu na to, z którym spośród nurtów liberalizmu mamy do czynienia, będzie on opierał się na pewnym, uniwersalnym dla wszystkich liberalizmów, kanonie wartości, a składa się nań: wolność, indywidualizm, własność prywatna. Pozostałe wartości i zasady są pochodnymi triady liberalnej: sprawiedliwość, ograniczenie funkcji państwa, ograniczenie roli aparatu państwowego, wiara w postęp ${ }^{46}$. Wg Johna Graya tym, co wspólne dla wszystkich wariantów liberalnej tradycji, jest koncepcja człowieka i społeczeństwa, która składa się z następujących elementów: „przede wszystkim jest indywidualistyczna, gdyż uznaje moralny prymat jednostki nad jakimikolwiek roszczeniami ze strony społeczeństwa; jest egalitarna, gdyż uznaje równość wszystkich ludzi i odrzuca wszelkie prawne czy polityczne porządki uznające różną wartość poszczególnych jednostek; jest uniwersalistyczna, gdyż głosi niezmienność natury ludzkiej i nadaje drugorzędne znaczenie kontekstom historycznym i formom kulturowym; jest wreszcie meliorystyczna, gdyż twierdzi, że wszelkie instytucje społeczne i polityczne są zdolne do samoregulacji" ${ }^{47}$.

Tytułowe widmo liberalizmu ma zatem liczne oblicza. Łączy je wprawdzie wspólny i niezmienny kanon wartości, zasad, lecz sposób postrzegania, definiowania oraz szeregowania jego poszczególnych elementów jest niezwykle zróżnicowany. Gdy dziś więc na polskiej scenie politycznej słyszymy przestrogi przed liberalizmem, a słowo „liberał” staje się inwektywą, pojawia się cały szereg pytań i wątpliwości. Jaki liberalizm mają na

45 Patrz: Oblicza liberalizmu. Isaiah Berlin, John Gray, Steven Lukes, Joseph Raz $w$ rozmowie z Beata Polanowska-Sykulska, Kraków 2003.

46 Lista ta będzie się rozszerzała wraz ze wzrostem poziomu szczegółowości.

47 J. Gray, op. cit., s. 8. 
myśli ci, którzy w dysputach politycznych nadali mu wymiar „,wszelakiego zła"? Który z nurtów liberalizmu niesie ze sobą największe zagrożenia, a jaka jego postać jest do zaakceptowania? W jaki sposób zatem definiowane są podstawowe wartości liberalne? Czy ten krytyczny stosunek do liberalizmu jest jednocześnie kwestionowaniem dorobku myślicieli poprzednich epok, od starożytności począwszy? A może ów antyliberalny charakter dyskursu prowadzonego przez pewną część sceny politycznej jest w rzeczywistości próbą stworzenia „nowego liberalizmu” - eklektycznego? Czy tę postać doktryny, która jawi nam się po przeanalizowaniu wypowiedzi polityków można nazwać ,antyliberalnym liberalizmem"?

W chaotycznej mozaice treści antyliberalnych można zaobserwować kilka wątków wiodących: 1) wartości, 2) ekonomia, 3) lumpenliberalizm. Pierwszą płaszczyznę tworzą przede wszystkim wypowiedzi, których autorzy liberalizmowi przeciwstawiają wartości chrześcijańskie oraz wsparta na ich fundamencie zdrową, tradycyjnie pojmowaną rodzinę. Wynika z nich, że liberalizm jest tak samo antyludzki jak antyrodzinny, a jego celem jest, z bliżej nieokreślonych powodów, jej unicestwienie. „Dla kręgów liberalnych i lewicowych solą w oku jest instytucjonalne umacnianie się katolików, a przez to umacnianie misji głoszenia Ewangelii i propagowanie wartości chrześcijańskich i patriotycznych"48. Przeprowadzona w pierwszej części niniejszego artykułu analiza korzeni liberalizmu zaprzecza tezie postawionej w zacytowanej wypowiedzi. Słysząc tego typu oceny mamy ochotę zapytać : „A co na to Tomasz z Akwinu, jezuici i dominikanie związani ze szkołą w Salamance?” Nawet jeśli zawęzimy liberalizm do sposobu definiowania człowieka: do indywidualizmu z jednej strony i personalizmu - z drugiej, to teza, iż liberalizm jest antychrześcijański nie może się utrzymać. W wielu nurtach liberalizmu spotkamy się z wyraźnym nastawieniem antyklerykalnym, ale nie można takiej postawy utożsamiać z odrzucaniem wartości chrześcijańskich. Nawet w oficjalnej nauce Kościoła, która na przestrzeni wieków była wyraźnie antyliberalna ${ }^{49}$ nie znajdziemy tak daleko idących wniosków. Poza tym ci spośród polityków, którzy podzielają tego typu zarzuty, zapominają niejako o tym,

48 Wypowiedź posła Krzysztofa Jurgiela na 1. posiedzeniu Sejmu w dn. 14.11.2007.

49 Może z wyjątkiem XIX-wiecznych papieży, choćby Piusa IX, którego encyklika Quanta cura, a zwłaszcza dołączony doń Sylabus faktycznie posuwa się równie daleko w swej totalnej krytyce liberalizmu. 
że chrześcijaństwo to nie tylko katolicyzm ${ }^{50}$, a wartości wypływające z Ewangelii stanowią fundament również doktryn protestanckich, które różni od katolicyzmu, między innymi, postrzeganie indywidualizmu ${ }^{51}$.

Równie niezrozumiałe są więc dramatyczne nawoływania: „Nie zabijajcie polskiej rodziny w imię fałszywie pojętych haseł liberałów, puszczania wszystkiego na żywioł, na kompletny luz"52. Wątpliwości, które budzi niniejsza wypowiedź, oddają słowa innego uczestnika debaty sejmowej: „Nie bardzo wiem, co to miałoby znaczyć i dlaczego akurat liberałowie mieliby mieć coś przeciwko rodzinom"53. Istotnie - nie znajdziemy ani w tradycji liberalnej, ani wśród tak licznych współczesnych nurtów liberalizmu słów, które mogłyby stanowić podstawę tego typu oskarżeń. Ponadto można odnieść wrażenie, że autor, mówiąc o ,puszczaniu wszystkiego na żywioł", myli liberalizm z libertynizmem.

Drugi wątek krytyki antyliberalnej ogniskuje się na problematyce ekonomicznej. Ta płaszczyzna „antyliberalnego liberalizmu” jest najmniej spójna i konsekwentna. Z jednej bowiem strony liberałom zarzuca się prowadzenie nomen omen liberalnej polityki, a więc zgodnej z regułami wolnego rynku, z drugiej natomiast - podkreśla efektywność mechanizmów wolnorynkowych. Być może ta sprzeczność wynika z przekonania, że liberałowie nie wiedzą czym jest wolny rynek i na jakich regułach się opiera! „Liberałowie udowodnili, że nie mają żadnych, najmniejszych kwalifikacji" ${ }^{54}$. Jeśli przyjmiemy, że chodzi o liberałów w ogóle, to taka konstatacja musi budzić wątpliwości, skoro wielu liberałów to uznani ekonomiści, a kilku z nich zostało uhonorowanych nagrodą Nobla w dziedzinie ekonomii właśnie. Jednak, gdy zawęzimy adresata i sprowadzimy go do partii z liberalizmem kojarzonej, czyli Platformy Obywatelskiej, problem jest jeszcze trudniejszy do rozwiązania. Wprawdzie tematyka niniejszego artykułu wykracza poza tę kwestię, ale jest konieczne nadmienić w tym miejscu, że do dziś istnieje problem ze zdefiniowaniem polskiego liberalizmu. Wyjątkowo trudne warunki rozwoju dla ideologii liberalnej,

50 Można spotkać się z określeniem zawłaszczającym: „wartości katolickie”, którym zagraża oczywiście ,presja środowisk liberalno-lewicowych” - Wypowiedź Artura Górskiego na 32. posiedzeniu Sejmu w dn. 19.02.2008.

51 „Radykalny indywidualizm jest wspólną postawą protestanta i liberała” - M. Novak, Liberalizm - sprzymierzeniec czy wróg Kościoła, Poznań 1993, s. 56.

52 Wypowiedź Beaty Kempy na 1. posiedzeniu Sejmu w dn. 14.11.2007.

53 Wypowiedź Marka Borowskiego na 1. posiedzeniu Sejmu w dn. 14.11.2007.

54 Wpowiedź Mariusza Kamińskiego na 1. posiedzeniu Sejmu w dn. 6.11.2007. 
związane ze swoistymi uwikłaniami historyczno-politycznymi ${ }^{55}$, zdeterminowały kształt liberalizmu w Polsce do tego stopnia, że można mieć wątpliwości czy jest to nadal liberalizm. Można spotkać się z opinią, iż, jeśli tak, to jest to liberalizm eklektyczny albo rozproszony. A zatem, wracając do cytatu, ,polscy liberałowie” to pojęcie abstrakcyjne, a więc dalsza cześć przytoczonego zdania nie ma po prostu sensu.

Krytyka liberalizmu w sferze ekonomicznej przeprowadzana jest w imieniu ludzi biednych i słabych. Przeciwstawiając liberalizm najbardziej upośledzonym grupom społecznym, definiuje się go jako przyczynę ich nieszczęść i niepowodzeń. „Obecny rząd zamierza przyjąć liberalny kurs, nieuwzględniający potrzeb najsłabszych grup społecznych, w tym niepełnosprawnych" ${ }^{, 56}$. Jak zatem pogodzić stwierdzenie, że „liberałowie nie mają żadnych kwalifikacji ekonomicznych" z następującą wypowiedzią krytyczną, adresowaną do parlamentarzystów z Platformy Obywatelskiej i Polskiego Stronnictwa Ludowego: „[dla was - przyp. N.K]

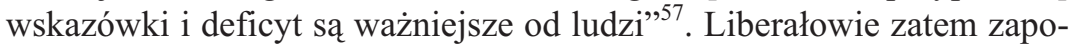
minają o człowieku, a skupiają się wyłącznie na liczbach. „Chcę powiedzieć, że różnica między myśleniem prospołecznym, myśleniem bardziej wrażliwym społecznie a przejawem liberalizmu w tym wymiarze złym, w negatywnym znaczeniu tego słowa, bo nikt nie jest przeciwko wolnej gospodarce rynkowej, pewnym kanonom gospodarczym, jeżeli chodzi o politykę społeczna, to trzeba głośno i wyraźnie powiedzieć [...] że wierność, wiernopoddańczość dogmatom, wskaźnikom, cytatom i różnym instrumentom ekonomicznym, a nie troska o człowieka w tym się właśnie przejawia" ${ }^{\text {. }}$. W zdaniu tym znalazły się dwa dyskusyjne sformułowania. Biorąc pod uwagę narodziny i ewolucję myśli liberalnej, zarówno na płaszczyźnie ekonomicznej, jak i politycznej, czy na którymkolwiek etapie rozwoju liberalizmu, w którymkolwiek nurcie liberalnym, znajdziemy treści antyhumanistyczne? Jakkolwiek oceniamy liberałów narrację o człowieku, jego usytuowaniu i relacjach w społeczeństwie, bez względu na to, czy liberalna definicja jednostki i społeczeństwa przekonuje nas, czy też odnosimy się doń krytycznie - mimo to nie sposób zapomnieć, że to właśnie liberalizm człowieka „wyzwolił” - i „wyzwala” nieustannie

55 Mowa tutaj oczywiście o zaborach i ponad czterdziestu latach przynależności do radzieckiej strefy wpływów.

56 Wypowiedź Waldemara Anzela na 3. posiedzeniu Sejmu w dniu 6.12.2007.

57 Wypowiedź Tadeusza Cymańskiego na 3. posiedzeniu Sejmu w dn. 6.12.2007.

58 Wypowiedź Tadeusza Cymańskiego na 4. posiedzeniu Sejmu w dn. 18.12.2007. 
- począwszy od sofistów, skończywszy na Hayeku, Rawlsie czy Nozicku. Drugie zaskoczenie, po przeczytaniu powyższego cytatu, pojawia się skutkiem słów: „nikt nie jest przeciwko wolnej gospodarce rynkowej”. A zatem mamy, wedle autora, do czynienia ze złym i dobrym liberalizmem. Jednak problem polega na tym, że nadal nie wiemy, jaka jest między nimi różnica. Liberałowie związani z Platformą Obywatelską są bowiem „wyznawcami” solidarnej polityki gospodarczej, którą, w ich mniemaniu, można pogodzić z liberalizmem gospodarczym. Można ekstrapolować z tego przywiązanie liberałów w polskim parlamencie do tradycji sprawiedliwości społecznej ${ }^{59}$. Paradoksalnie, do tej samej tradycji odwołują się najbardziej zagorzali krytycy liberalizmu. Ich postawę możemy określić mianem liberalizmu nieuświadomionego, czy też odrzuconego. Sytuujący się na polskiej scenie politycznej zdeklarowani krytycy liberalizmu zdają się zawężać to pojęcie do leseferystycznej utopii, zapominając jednocześnie, jaki sens i znaczenie ma utopia jako taka. Przyjmując treści liberalizmu, ukrywają je jednocześnie za parawanem nominum solidaryzmu społecznego, które rzekomo stoi w opozycji do liberalizmu właśnie. Stąd brak precyzji w wystapieniach niektórych, antyliberalnie nastawionych, polityków, chociażby wówczas, gdy pada oskarżenie: „[...] likwidacja, zrujnowanie [gospodarki morskiej - przyp. N.K.], to jedna z największych win polskiego liberalizmu. Nie było żadnych przesłanek do tego, by ją niszczyć" ${ }^{60}$. Dalszy ciąg tej wypowiedzi nie rozwiewa, niestety, pojawiających się wątpliwości. Trudno bowiem odnaleźć w historii myśli liberalnej, a także wśród jej współczesnych nurtów, treści, które mogłyby stanowić podstawę tego typu oskarżeń. Śmiało natomiast można stwierdzić, że liberał, który dopuszcza świadome niszczenie gospodarki, nie zasługuje na to miano. Można liberałom zarzucić dogmatyzm gospodarczy, ale nie działanie na szkodę gospodarki.

59 Zarówno w wydaniu J. Rawlsa, jak również w tym ujęciu, które jest bliskie nauce społecznej Kościoła. Uznawany za politycznego przywódcę polskich liberałów premier Donald Tusk w jednym z wywiadów na pytanie dziennikarzy: „Jak by pan premier określił dzisiaj swoje poglądy gospodarcze?” odpowiedział: „Przyjmijmy, że liberała zostało we mnie ...64 proc. [...] Na pewno od 1989 roku nie było w Polsce na stanowisku premiera człowieka o tak jednoznacznie liberalnych poglądach gospodarczych" - Jestem liberałem na 64 proc. Z premierem Donaldem Tuskiem rozmawiają: J. Solska, J. Baczyński, P. Tarnowski, „Polityka”, nr 18, 3 maja 2008, s. 15.

${ }^{60}$ M. Chodurski, Upadek stoczni to efekt liberalizmu, IAR/PAP 23.10.2010, http://www.polskieradio.pl. 
Ostatnim już wątkiem, składającym się na antyliberalną krytykę polskich polityków, jest lumpenliberalizm. Definicję i źródła tego zjawiska przedstawił lider PiS, Jarosław Kaczyński. Jego zdaniem korzenie lumpenliberalizmu tkwią w późnym komunizmie (!) z jednej strony, z drugiej natomiast - w obozie solidarnościowym. Inspiracją dla tej etymologii i słowotwórstwa prawdopodobnie była książka Głowy hydry prof. Anny Pawełczyńskiej. To właśnie w tej pracy, przeprowadzając krytykę III Rzeczpospolitej, autorka posługuje się pojęciem „lumpenelity”. Za tym określeniem kryją się „ludzie tkwiący korzeniami w PRL” "61. Jednakże problem ten już w latach 90. XX wieku zauważył prof. Jerzy Szacki, definiując jego źródło: „Paradoksalnie «liberałami» okazują się dziś najbardziej wpływowi «postkomuniści», ponieważ nie dopuścili oni do radykalnego zerwania z polityką prokapitalistycznych reform i kontynuują $\mathrm{w}$ takim lub innym stopniu to, co robili ich - bardziej programowo liberalni - poprzednicy" ${ }^{\prime 2}$.

Prezes Prawa i Sprawiedliwości twierdzi, że lumpenliberalizm ,[...] pozwalał z jednej strony uzasadnić nadużycie, jako sposób budowania gospodarki kapitalistycznej, a z drugiej strony pozwala twierdzić najpoważniej w świecie, że wolność to sex-shopy, że można powiedzieć, głównie wolność w tej sferze się sytuuje [...], a że głównym zagrożeniem dla wolności w Polsce jest Kościół”, "Ta wypowiedź zdaje się być konkretyzacją słów prof. Pawełczyńskiej: „W liberalizmie, wzorem pewnych doświadczeń wyniesionych z komunizmu, przemoc fizyczną zastąpiła przemoc ekonomiczna i przemoc nad świadomością. Istota sprawy pozostaje jednak ta sama. To nieważne, że przemoc nad świadomością nie boli, nie zabija w sensie fizycznym, ale ona zabija, okalecza duchowość człowieka, jego życie i zdolność do współżycia z innymi. Wszystkie totalitaryzmy łączy relatywizm moralny, tj. brak wspólnych zasad moralnych, które regulują współżycie. A także głoszenie antyreligii..."64. Tym samym lumpenliberalizm staje się klamrą spinającą różne wątki w jedną wspólną antyliberalną płaszczyznę. Lumpenliberalizm, który uzasadnia antyliberalną krytykę, walczy z wartościami chrześcijańskimi (katolickimi), na

61 Alfabet IV RP, http://wyborcza.pl, 6.11.2010.

62 J. Szacki, (Anty)liberalizm i (anty)populizm. Ukryty podziat, „Polityka”, nr 50, 14 grudnia 1996, s. 74.

${ }_{63}$ Wypowiedź Jarosława Kaczyńskiego na 13. posiedzeniu Sejmu 14.03.2006.

${ }^{64}$ Liberalizm - trzecia głowa Hydry. Rozmowa Małgorzaty Goss z prof. Anną Pawełczyńską, http://webcache.googlesercontent.com, s. 3. 
płaszczyźnie ekonomicznej prowadzi do uprzedmiotowienia człowieka, na płaszczyźnie politycznej stanowi spisek bliżej nieokreślonych sił liberalnych i komunistycznych (postkomunistycznych). Jego wyraźnie aferalny wymiar ${ }^{65}$ jest rzekomo pokłosiem działalności Leszka Balcerowicza, Jana Marii Rokity i Donalda Tuska ${ }^{66}$, a więc postaci utożsamianych z polskim liberalizmem.

Wymienione wcześniej trzy wątki antyliberalizmu odnoszą się do wypowiedzi i postaw polskich polityków kilku ostatnich lat. Jednak ów specyficzny antyliberalizm został zlokalizowany i zdefiniowany już wcześniej jako: „(1) zapatrzenie się na kapitalistyczny Zachód, połączone z brakiem zrozumienia dla swoistych tradycji i potrzeb polskiego społeczeństwa [...], (2) kult wolnego rynku i wolnej konkurencji; totalna negacja potrzeby interwencjonizmu państwowego, (3) godzenie się na wzrost nierówności i niesprawiedliwość społeczną, (4) absolutyzacja wskaźników ekonomicznych połączona z lekceważeniem problemów społecznych, [...], (7) immoralizm lub wręcz uznanie, iż racja jest zawsze po stronie ekonomicznie silniejszego"67. To właśnie tytułowe widmo liberalizmu. Tymczasem liberalizmu nie można sprowadzać do tego typu postulatów, ponieważ, po pierwsze, nie oddaje to złożoności zagadnienia, a po drugie - jest poważnym przekłamaniem. Zatem antyliberalne treści wypowiedzi polskich polityków mają podłoże czysto demagogiczne. Ich autorom przyświecają wyłącznie cele polityczne, a antyliberalne hasła, nawet jeśli ich podstawa jest wątpliwa, są instrumentem służącym do pogrążania przeciwnika. Zasadniczy problem polega jednak na tym, że w ten sposób wśród wyborców utrwalony zostaje mylny obraz liberalizmu - jego widmo...

\section{Summary}

The notion of 'liberalism' is beginning to acquire a new meaning in Polish political discourse. This 'new liberalism' is actually a distortion of liberal thinking and does not have much in common with proper liberalism. It has become a demon that politicians with anti-liberal attitudes use to frighten their potential voters. The reason for that is that their political opponents are associated with liberalism. Therefore, the author attempts to identify liberalism and the directions of its evolution in order to emphasize the fact that the fundamental values of liberalism do not actually correspond to the anti-liberal claims employed in political disputes.

\footnotetext{
${ }^{65}$ Wypowiedź Jacka Kurskiego na 13. posiedzeniu Sejmu w dn. 14.03.2006.

${ }^{66}$ Alfabet IV RP, op. cit.

67 J. Szacki, op. cit.
} 